\title{
Early failure of noninvasive ventilation in chronic obstructive pulmonary disease with acute hypercapnic respiratory failure
}

\author{
H Cho*, S Ahn, K Lim, W Kim, Y Lee, B Ko \\ From ESICM LIVES 2015 \\ Berlin, Germany. 3-7 October 2015
}

\section{Objectives}

Noninvasive ventilation (NIV) in the management of chronic obstructive pulmonary disease (COPD) patient with acute hypercapnic respiratory failure is considered a first-line therapy. However, higher mortality was shown in patients receiving transition from NIV to invasive mechanical ventilation than in patients receiving invasive mechanical ventilation from the first management. We tried to find parameters associated with early NIV failure in patients presenting to ED with acute exacerbation of COPD.

\section{Methods}

Medical records of 218 patients with acute exacerbation of COPD visiting Asan Medical Center and managed with NIV during their stay in the ED from January 2007 to December 2013 were analyzed.

\section{Results}

NIV was successful in 191 (87.6\%) and 27 (12.4\%) failed NIV treatment. Of the variables obtained before NIV treatment, heart rate ( $\geq 120 / \mathrm{min}$ : OR $2.8,95 \%$ CI 1.1 - 6.8) and $\mathrm{pH}$ (7.25 - 7.29: OR 2.6, 95\% CI 1.8 - 8.1; < 7.25: OR 15.2, 95\% CI 5.0 - 46.1) were significant factors associated with early NIV failure. Of the variables obtained after $1 \mathrm{hr}$ of NIV treatment, heart rate $(\geq 120 / \mathrm{min}$ : OR $4.0,95 \% \mathrm{CI}$ 1.4 - 11.5) and pH (7.25 - 7.29: OR 4.7, 95\% CI 1.5 - 15.1; < 7.25: OR 29.8, 95\% CI 15.7 - 62.7) were still significant.

\section{Conclusions}

Presence of tachycardia and severe acidosis before NIV treatment, and persistence of tachycardia and severe acidosis after 1hour of NIV treatment predicted early NIV failure.

Asan Medical Center, Department of Emergency Medicine, Seoul, Korea, Republic of

(c) 2015 Cho et al.; This is an Open Access article distributed under the terms of the Creative Commons Attribution License (http:// creativecommons.org/licenses/by/4.0), which permits unrestricted use, distribution, and reproduction in any medium, provided the original work is properly cited.
Published: 1 October 2015

\section{References}

1. Brochard L, Mancebo J, Wysocki M, Lofaso F, Conti G, Rauss A, Simonneau G, Benito S, Gasparetto A, Lemaire F, et al: Noninvasive ventilation for acute exacerbations of chronic obstructive pulmonary disease. N Engl J Med 1995, 333(13):817-822, doi:10.1056/ NEJM199509283331301.

2. Kramer N, Meyer TJ, Meharg J, Cece RD, Hill NS: Randomized, prospective trial of noninvasive positive pressure ventilation in acute respiratory failure. American journal of respiratory and critical care medicine 1995, 151(6):1799-1806, doi:10.1164/ajrccm.151.6.7767523.

3. Lightowler JV, Wedzicha JA, Elliott MW, Ram FS: Non-invasive positive pressure ventilation to treat respiratory failure resulting from exacerbations of chronic obstructive pulmonary disease: Cochrane systematic review and meta-analysis. BMJ 2003, 326(7382):185.

4. Ram FS, Picot J, Lightowler J, Wedzicha JA: Non-invasive positive pressure ventilation for treatment of respiratory failure due to exacerbations of chronic obstructive pulmonary disease. Cochrane Database Syst Rev 2004, 3: CD004104, doi:10.1002/14651858.CD004104.pub3.

5. Soo Hoo GW, Santiago S, Williams AJ: Nasal mechanical ventilation for hypercapnic respiratory failure in chronic obstructive pulmonary disease: determinants of success and failure. Critical care medicine 1994, 22(8):1253-1261.

doi:10.1186/2197-425X-3-S1-A671

Cite this article as: Cho et al:: Early failure of noninvasive ventilation in chronic obstructive pulmonary disease with acute hypercapnic respiratory failure. Intensive Care Medicine Experimental 2015 3(Suppl 1):A671.

Submit your manuscript to a SpringerOpen ${ }^{\odot}$ journal and benefit from:

- Convenient online submission

- Rigorous peer review

- Immediate publication on acceptance

- Open access: articles freely available online

- High visibility within the field

- Retaining the copyright to your article

Submit your next manuscript at $>$ springeropen.com 